\title{
Effects of Glycaemic Status on Plasma Levels of Calcium, Chromium, Copper, Iron, Magnesium, Selenium and Zinc in Diabetic Rats
}

\author{
Ugwuja E. I. ${ }^{1, *}$, Ugwu N. C. ${ }^{1}$, Aloke $C^{2}$, Ide nyi JN ${ }^{3}$, Nwibo AN ${ }^{1}$, Ibiam UA ${ }^{4}$, Eze nkwa US ${ }^{1}$ \\ ${ }^{1}$ Department of Chemical Pathology, Faculty of Clinical Medicine, Ebonyi State University, P.M.B. 053, Abakaliki, Nigeria \\ ${ }^{2}$ Department of Medical Biochemistry, Faculty of Basic Medical Sciences, Ebonyi State University, P.M.B. 053 Abakaliki, Nigeria \\ ${ }^{3}$ Department of Biotechnology, Faculty of Biological Sciences, Ebonyi State University, P.M.B .053, Abakaliki, Nigeria \\ ${ }^{4}$ Department of Biochemistry, Faculty of Biological Sciences, Ebonyi State University, P.M.B .053, Abakaliki, Nigeria
}

\begin{abstract}
There is increasing evidence of the involvement of minerals in the pathogenesis of diabetes mellitus and its complications. In order to determine the effects of glycaemic status on the plasma levels of calcium, chromium, copper, iron, magnesium, selenium and zinc, 24 alb ino rats weighing 105-162 g grouped into 4 \{non-diabetic control (NDC), diabetic control (DC), and diabetic treated with $10 \mathrm{mg} / \mathrm{Kg}$ body weight $\left(\mathrm{DT}_{10}\right)$ and $20 \mathrm{mg} / \mathrm{Kg}$ body weight $\left(\mathrm{DT}_{20}\right)$ of glucophage respectively \}, were investigated. In addition to fasting plasma glucose, plasma levels of elements were determined by atomic absorption spectrophotometer. Results show that diabetic rats had lower levels of the elements in comparison to their non-diabetic counterparts but only magnesium $\{37.5(1.9)$ vs. $48.8(3.4) ; \mathrm{p}=0.033)\}$, copper $\{13.5(0.9)$ vs. $24.9(0.7) ; \mathrm{p}=$ $0.032)\}$ and zinc $\{34.9(0.7)$ vs. $58.2(0.6) ; \mathrm{p}=0.013)\}$ were statistically significant. Again, higher levels of the elements were observed in diabetic treated rats when compared to the diabetic control but only copper $\{22.5(0.3)$ vs. $13.5(0.9), \mathrm{p}=$ $0.043)\}$ and zinc $\{49.6(0.7)$ vs. $34.9(0.7), \mathrm{p}=0.028)\}$ were found to be significant, at higher dosage of the antihyperglycaemic agent. Plas ma glucose was negatively correlated with copper $(r=-0.273 ; p=0.017)$, magnesium $(r=$ $-0.212 ; p=0.024$ and zinc $(r=-0.245 ; p=0.019)$, with no significant relationship observed among the elements. We conclude that hyperglycaemia of diabetes alters plas ma mineral levels with plasma copper, magnesium and zinc being more responsive to alterations in glycaemic status than calcium, chro mium, iron and selenium.
\end{abstract}

Keywords Hyperglycaemia, Mineral Metabolism, Diabetic Complications, Antihyperglycaemic Agent

\section{Introduction}

Diabetes mellitus, a metabolic syndrome characterized by hyperglycaemia and glycosuria is caused by absolute or relative lack of insulin, insulin resistance or both. It is estimated that diabetes affects about 170 million people world-wide[1]. Trace elements have been recognized as essential for optimal cellular functions, where they serve a variety of catalytic, structural and regulatory functions and in which they interact with macromolecules such as enzymes, pro-hormones, pre-secretory granules and biological membranes [2]. Although association of trace elements with health and disease has been established[3], the relationship between trace element metabolism and the aetiology and complications of diabetes mellitus is still a subject of intensive debate.

For instance, while some studies[3-6] have documented

* Corresponding author:

ugwuja@yahoo.com (Ugwuja E. I.)

Published online at http://journal.sapub.org/diabetes

Copyright (C) 2012 Scientific \& Academic Publishing. All Rights Reserved lower plas ma levels of zinc in diabetic subjects, others $[2,7,8]$ reported no change in zinc levels. Similarly, reports on other trace elements in diabetes mellitus can best be described as inconsistent[2-8]. Although diabetes mellitus has been linked to perturbations of mineral metabolis $m$, it is not clear whether it is diabetes and hyperglycaemia that affect mineral metabolism or if it is alterations in mineral homeostas is that influences carbohydrate metabolism[6,9,10. This study is therefore design to evaluate the effect of glycaemic status on the plasma levels of calcium, chromium, copper, iron, magnesium, selenium and zinc in alloxan - induced diabetic rats.

\section{Materials and Methods}

Male Wister albino rats $(\mathrm{n}=24)$, weighing 105-162 g purchased from animal house of the Department of Pharmacy, University of Nigeria, Nsukka were randomly assigned into four (4) groups (I-IV) of six (6) rats per group. They were kept in standard cages at $25^{\circ} \mathrm{C}$ and $12 \mathrm{~h} \mathrm{light/dark}$ condition in the animal room of the Department of 
Biochemistry, Ebonyi State University, Abakaliki. The animals were fed on commercial rats' feeds and were given water ad libitum for a period of two week to allow them acclimatize. All the rats received human care in accordance with the National Institute of Health guidelines for the care and use of laboratory animals[11].

Group I rats acted as non-diabetic control (NDC) and were maintained on feed and water. Rats in groups II-IV were made diabetic by intraperitoneal injection of $200 \mathrm{mg} / \mathrm{Kg}$ body weight of alloxan dissolved in distilled water. Fasting blood glucose levels were measured after three days of alloxan injection with a glucometer (ACCUTREND GC (Boerh inger, Mannheim, Germany), using blood from the tail tips and diabetes mellitus was confirmed by elevated blood glucose $>7.8 \mathrm{mmo} / 1 /$. Group II rats were thereafter maintained on feed and water and acted as diabetic control (DC). For the rats in group III $\left(\mathrm{DT}_{10}\right)$ and IV $\left(\mathrm{DT}_{20}\right)$ they were in addition to normal feed and water administered oral antihyperglycaemic agent-Metformin (glucophage) at a dose of $10 \mathrm{mg} / \mathrm{Kg}$ body weight and $20 \mathrm{mg} / \mathrm{Kg}$ body weight daily, respectively.

The dosage of Metformin used in this experiment was arrived at based on the normal dosage used in human $(1000-1500 \mathrm{mg} /$ day $)$. For a $70 \mathrm{Kg}$ man, it means $1000-1500$ $\mathrm{mg} / 70 \mathrm{Kg}$, which amounts to $14.3-21.4 \mathrm{mg} / \mathrm{Kg}$ body weight. Thus we approximated the dose to $10-20 \mathrm{mg} / \mathrm{Kg}$ body weight.

The experiment lasted for 28 days after which the rats were anaesthetized in a chloroform saturated chamber and the fasting blood samples were collected by cardiac puncture. The blood samples were dispensed into fluoride oxalate and heparinised bottles for the estimation of plasma glucose and mineral elements respectively. The blood was spun at $2000 \mathrm{~g}$ for 5 minutes and plasma separated into previously chemically cleaned screw cap bottles. While plasma glucose was determined immediately, plasma for mineral element analyses were stored frozen $\left(-8^{\circ} \mathrm{C}\right)$ before analyses. Plas ma glucose was determined by glucose oxidase method[12] while plas ma mineral elements were determined by atomic absorption spectrophotometer (AAS). Data were analysed for mean and standard deviation. Co mparis on of parameters among groups was done by one-way analysis of variance (ANOVA) and $\mathrm{p}$ value less than 0.05 was considered as statistically significant.

\section{Results}

The initial fasting plasma glucose levels of the diabetic rats irrespective of treat ment were significantly higher when compared to the level in non-diabetic rats (Table 1). However, fasting plasma glucose levels were significantly lower in the treated rats in comparison to their untreated counterparts. The observed glucose lowering effect of glucophage was dose dependent, with a dose of $20 \mathrm{mg} / \mathrm{Kg}$ body reducing plasma glucose by $56.9 \%$ against the $44.5 \%$ observed with a dose of $10 \mathrm{mg} / \mathrm{Kg}$ body weight.
Table 1. Comparison of Body Weight and Fasting Plasma Glucose among the Experimental Rat Groups

\begin{tabular}{ccccc}
\hline Parameters & NDC & DC & DT $_{10}$ & DT $_{20}$ \\
\hline $\begin{array}{c}\boldsymbol{F P G} \\
(\boldsymbol{m m o l} / \boldsymbol{l})\end{array}$ & & & & \\
Initial & $5.6 \pm 0.9^{\mathrm{a}}$ & $13.3 \pm 0.7^{\mathrm{b}}$ & $14.6 \pm 0.5^{\mathrm{b}}$ & $13.7 \pm 0.4^{\mathrm{b}}$ \\
Final & $5.7 \pm 0.6^{\mathrm{a}}$ & $13.9 \pm 0.6^{\mathrm{b}}$ & $8.1 \pm 0.8^{\mathrm{a}}$ & $5.9 \pm 0.3^{\mathrm{a}}$ \\
Change & $+0.1(1.8)$ & $+0.6(4.5)$ & $-6.5(44.5)$ & $-7.8(56.9)$ \\
$\quad(\%)$ & & & & \\
Body & & & & \\
weight & & & & \\
$($ Kg $)$ & & & & \\
Initial & $150.3 \pm 21.9$ & $149.1 \pm 16.9$ & $151.1 \pm 12.5$ & $152.6 \pm 13.9$ \\
Final & $164.1 \pm 22.3^{\mathrm{a}}$ & $139.2 \pm 16.9^{\mathrm{b}}$ & $144.7 \pm 11.3^{\mathrm{b}}$ & $149.4 \pm 15.7^{\mathrm{b}}$ \\
Change & $+13.8(9.2)$ & $-9.9(6.6)$ & $-6.4(4.2)$ & $-3.2(2.1)$ \\
$(\%)$ & & &
\end{tabular}

Values carrying different superscripts horizontally are signi ficantly di fferent NDC: Non-diab etic control; DC: Diabetic control; DT 10: Diabetics treated with $10 \mathrm{mg} / \mathrm{Kg}$ body weight glucophage; $\mathbf{D T}_{\mathbf{2 0}}$ : Diabetics treated with $20 \mathrm{mg} / \mathrm{Kg}$ body weight glucophage

Table 2 shows that diabetic rats in general had lower levels of the elements in comparison to their non-diabetic counterparts, although only magnesium, copper and zinc were statistically significant $(37.5 \pm 1.9$ vs. $48.8 \pm 3.4 ; \mathrm{p}=$ $0.033,13.5 \pm 0.9$ vs. $24.9 \pm 0.7 ; \mathrm{p}=0.032$ and $34.9 \pm 0.7 \mathrm{vs}$. $58.2 \pm 0.6 ; \mathrm{p}=0.013$, respectively). Again, higher levels of the elements were observed in diabetic treated rats when compared to the diabetic control but only copper and zinc were found to be significant $(\mathrm{p}<0.05)$ at higher dosage of antihyperglycaemic agent $(22.5 \pm 0.3$ vs. $13.5 \pm 0.9, \mathrm{p}=$ 0.043 and $49.6 \pm 0.7$ vs. $34.9 \pm 0.7, p=0.028$, respectively).

Table 2. Comparison of Mineral Elements among the Experimental Rat Groups

\begin{tabular}{|c|c|c|c|c|}
\hline $\begin{array}{c}\text { Parameters } \\
(\mu \mathrm{mol} / \mathrm{l})\end{array}$ & NDC & DC & $\mathrm{DT}_{10}$ & $\mathrm{DT}_{20}$ \\
\hline $\mathrm{Mg}$ & $48.8 \pm 3.4$ & $37.5 \pm 1.9^{\dagger}$ & $39.4 \pm 1.7$ & $\begin{array}{c}43.2 \pm \\
2.2^{\neq}\end{array}$ \\
\hline $\mathrm{Ca}$ & $18.6 \pm 1.6$ & $17.0 \pm 1.7$ & $17.2 \pm 1.2$ & $18.4 \pm 1.4$ \\
\hline $\mathrm{Cu}$ & $24.9 \pm 0.7$ & $13.5 \pm 0.9^{\dagger}$ & $15.6 \pm 0.3^{\dagger}$ & $\begin{array}{c}22.5 \pm \\
0.3^{\ddagger}\end{array}$ \\
\hline $\mathrm{Zn}$ & $58.2 \pm 0.6$ & $34.9 \pm 0.7^{\dagger}$ & $38.4 \pm 0.4^{\dagger}$ & $\begin{array}{c}49.6 \pm \\
0.7^{\neq}\end{array}$ \\
\hline $\mathrm{Se}$ & $13.3 \pm 0.7$ & $9.7 \pm 0.2$ & $10.4 \pm 0.4$ & $11.7 \pm 0.5$ \\
\hline $\mathrm{Cr}$ & $20.3 \pm 0.1$ & $17.0 \pm 0.6$ & $17.7 \pm 0.5$ & $18.9 \pm 0.4$ \\
\hline $\mathrm{Fe}$ & $28.3 \pm 1.2$ & $26.2 \pm 0.9$ & $26.7 \pm 0.6$ & $27.8 \pm 0.3$ \\
\hline
\end{tabular}

NDC: Non-diabetic control; DC: Diabetic control; DT $_{10}$ : Diabetics treated with $10 \mathrm{mg} / \mathrm{Kg}$ body weight glucophage; $\mathbf{D T}_{\mathbf{2 0}}$ : Diabetics treated with $20 \mathrm{mg} / \mathrm{Kg}$ body weight glucophage. "isignificantly different from non-diabetic control. ${ }^{\neq}$ significantly different from diabetic control

Correlation analysis showed that plasma glucose was significantly $(\mathrm{p}<0.05)$ negatively correlated with copper $(\mathrm{r}=$ $-0.273 ; \mathrm{p}=0.017)$, magnesium $(\mathrm{r}=-0.212 ; \mathrm{p}=0.024$ and zinc $(\mathrm{r}=-0.245 ; \mathrm{p}=0.019)$, but no significant relationship was observed among the elements (data not shown).

\section{Discussion}

This study has showed that hyperglycaemia of diabetes generally alters plasma mineral element levels, but only 
magnesium, copper and zinc levels were significantly affected. Also weight loss in diabetes mellitus can be reduced by treatment with glucophage even as plasma glucose is reduced. Few studies were encountered on the influence of diabetic hyperglycaemia on plasma trace ele ment levels and these studies assessed mainly tissue levels of trace elements and were old[13, 14]. For instance, in the study of the influence of chronic diabetes on tis sue and blood cell status of $\mathrm{Zn}, \mathrm{Cu}$ and $\mathrm{Cr}$ in rats, Razi and Havivi[13] reported elevated contents of $\mathrm{Zn}$ and $\mathrm{Cu}$ in the liver, femur, erythrocytes and lymphocytes of diabetic rats with increased urinary loss of the elements.

Similarly, both $\mathrm{Cu}$ and $\mathrm{Zn}$ have been found to accumulate in the liver and kidneys of streptozotocin treated rats one week after injection and increased thereafter, attaining two and five fold higher, respectively by four weeks[14]. Significantly lower plasma $\mathrm{Cu}, \mathrm{Mg}$ and $\mathrm{Zn}$ in diabetic rats in comparison to non-diabetic rats observed in the present study corroborated the finding of Hussain et al.,[3] where $\mathrm{Zn}$ and $\mathrm{Mg}$ levels were reported to be lower in diabetics in comparison to non-diabetics and that of Anjum et al.[4] in which significantly lower level of $\mathrm{Zn}$ was reported in diabetic subjects in comparison to their non-diabetic counterparts. It however contrasted lack of effects on plasma $\mathrm{Zn}, \mathrm{Cu}$ and $\mathrm{Cr}$ reported by Babalola et al.[7] and on $\mathrm{Zn}[2]$ and $\mathrm{Mg}[2,5]$ or on zinc [15], as well as higher plasma copper in diabetics reported by some authors[2, 4, 6]. Previously, significantly reduced mean levels of $\mathrm{Zn}, \mathrm{Mn}$, and $\mathrm{Cr}$ in blood and scalp-hair samples have been reported in diabetic patients when compared to control, with urinary excretion of the elements also significantly higher in diabetic subjects[13]. Also, low serum levels of $\mathrm{Zn}, \mathrm{Cr}$ and $\mathrm{Mg}$ had been reported in diabetics compared to control subjects which the authors suggested may be due to the poor glycaemic control[17].

Although, the cause of reduced levels of $\mathrm{Cu}, \mathrm{Mg}$ and $\mathrm{Zn}$ observed in the present study is not obvious, it could be partly attributed to increased urinary excretion of the elements as a result of osmotic diuresis. It has been earlier reported that diabetes and poor glycaemic control alter the metabolism of zinc and magnesium by increasing their urinary excretion and lowering serum levels[18]. Alternatively, decreased intestinal absorption of the elements may also be a factor[19], although evidence supporting this proposal is still weak[18]. It has been speculated that hyperglycaemia may interfere with the active transport of zinc back into the renal tubular cells [19]. Also diabeticassociated glycosuria has been reported to impair renal tubular absorption of magnesium fro $m$ the glo meru lar filtrate [20].

The significantly higher plasma levels of $\mathrm{Cu}$ and $\mathrm{Zn}$ in diabetic rats treated with $20 \mathrm{mg} / \mathrm{Kg}$ body weight of glucophage $\left(\mathrm{DT}_{20}\right)$ in comparison to diabetic control (DC) observed in the present clearly shows that glycaemic control in diabetes mellitus have effect on plasma macro- and trace element levels. As blood glucose is brought down from 13.7 (0.4) to $8.1(0.3)$, plas ma $\mathrm{Cu}$ and $\mathrm{Zn}$ levels were increased from $13.5(0.9)$ and $34.9(0.7) \mu \mathrm{mo} / 1 / 1$, respectively to 22.5
$(0.3)$ and $49.6(0.7) \mu \mathrm{mo} 1 / 1$, respectively. This observation is consistent with that of earlier study[18]. It is also in agreement with the study of Paolisso[21] who observed that glycaemic control in patients with type 2 diabetes may not correct low $\mathrm{Mg}$ concentration. Although the mechanism underlying these observations is not obvious, reduced urinary excretion of these elements with good glycaemic control may be a possibility as increased urinary exc retions of trace elements in poor glycaemic control have been attributed to hyperglycaemia, glucosuria and osmotic diuresis[22].

The significant inverse correlation between fasting plasma glucose and plasma $\mathrm{Cu}, \mathrm{Mg}$ and $\mathrm{Zn}$, respectively, observed in this study is in contrast with the finding of Akhuemokhan et al.[15] where serum concentration of $\mathrm{Zn}$ was neither correlated with fasting blood glucose nor glycated haemoglobin.

Also there were no relationships among the trace elements. This is in contrast to a positive correlation between $\mathrm{Cu}$ and $\mathrm{Zn}$ in type 1 diabetes mellitus[8], negative correlation between $\mathrm{Cu}$ and $\mathrm{Zn}$ in diabetic patients [6] and between $\mathrm{Zn}$ and $\mathrm{Mg}$ reported among diabetics in Calabar, Nigeria[18]. The difference in the findings of these studies with the present study may be partly attributed to difference in subjects. The studies were either conducted in type 1 diabetes[8] or diabetics in general (type 1 and 2)[6, 18], unlike the present study which was done in type 1 diabetic model

Although in the present study, hyperglycaemia of diabetes seems to alter other trace elements, including $\mathrm{Cr}, \mathrm{Fe}$, Se and $\mathrm{Ca}$, the effect was not significant, suggesting that their response to acute glycaemic alterations were not efficient. However, studies have associated these elements with either incidence of diabetes or pathogenesis of diabetic complications $[15,23,24]$. The proposed mechanism of action of trace elements in the pathophysiology of diabetes mellitus include improvements in insulin receptor / postreceptor signalling, leading to increased glucose transport by enhanced activity of the hormone-sensitive Glut-4 transporters [25], acting as a component or cofactor of enzy mes involved in glucose metabolism[26], and acting as antioxidants, thus prevention the peroxidation of biomelucules [27, 28].

\section{Conclusions}

This study reaffirms that diabetes mellitus alters trace element metabolism with plasma copper, magnesium and zinc being more responsive to alterations in glycaemic status than calcium, chromium, iron and selenium. However, further study is desired to evaluate the effect of short-and long-term effects of diabetic hyperglycaemia on plas ma levels of mineral elements.

\section{ACKNOWLEDGEMENTS}


The authors wish to acknowledge the technical staff of the Departments of Chemical Pathology, Medical Biochemistry and Biotechnology for logistic support.

\section{REFERENCES}

[1] Wokoma FS. Diabetes and hypertension in Africa - an overview, Diabetes International, vol. 12, pp. 36-40, 2002.

[2] Zargar AH, Shah NA, Massodi SR. Copper, zinc and magnesium levels in non-insulin-dependent diabetes mellitus. Postgraduate Medical Journal vol. 74, pp. 665-8, 1998.

[3] Hussain F, Arif Maan M, Sheikh MA, Nawaz H and Jamil A. Trace elements status in type 2 diabetes. Bangladesh Journal of Medical Science, vol. 8, Number 3, 2009.

[4] Anjum A,Yousaf M, Zuber M, Bukhari TM, Zahoor AF, Khan ZI, Naheed S, Ali KG, Purveen B, Ahmad K, Mukhtar MK, Hina S, Ahmad S, Tariq MU and Hussain G. A comparative study on the status of $\mathrm{Zn}$ and $\mathrm{Cu}$ in diabetic and non diabetic males in Punjab, Pakistan. African Journal of Pharmacy and Pharmacology, vol. 6(20), pp. 1482-1486, 2012.

[5] Masood N, Baloch GH, Ghori RA, Memon IA, Memon MA and Memon AS. Serum Zinc and Magnesium in Type-2 Diabetic Patients. Journal of the College of Physicians and Surgeons Pakistan, vol. 19(8), pp. 483-486, 2009.

[6] Viktorínová A, Toserová E, Krizko M, Duracková Z. Altered metabolism of copper, zinc, and magnesium is associated with increased levels of glycatedhemoglobin in patients with diabetes mellitus. Metabolism, vol. 58, pp. 1477-1482, 2009.

[7] Babalola OO, Ojo LO, Akinleye AO et al. Status of the levels of lead and selected trace elements in type 2 diabetes mellitus patients in Abeokuta, Nigeria. African Journal of Biochemistry Research, vol. 1, pp. 127-131, 2007.

[8] Evliy aoglu O, Kilicaslan N, Uzuncan N, Karaca B, Kocaclebi $\mathrm{A}$, Yensel $\mathrm{N}$ and Inci S. Serum levels of $\mathrm{Cu}$, Zinc, $\mathrm{Mg}$ in type 1 and 2 diabetic patients. $17^{\text {th }}$ Turk National Congress, pp. 285-286, 2004.

[9] Zheng Y, Li XK, Wang Y and Cai L. The role of zinc, copper and iron in the pathogenesis of diabetes and diabetic complications: therapeutic effects by chealator. Haemoglobin, vol. 32(1-2), pp. 135-45, 2008.

[10] Zhao C, Wang H, Zhang J, Feng L. Correlations of trace elements, glucose and body compositions in type 2 diabetics. Wei Sheng Yan Jiu., vol. 37(5), pp. 601-605, 2008.

[11] National Research Council (NRC). Guide for the care and use of laboratory animals. Publication No. 8523 (Rev), National Institute of Health, Bethesda, MD, 1985.

[12] Barham D. and Trinder P. An improved colour reagent for the determination of blood glucose by oxidase system. Analyst, vol. 27, pp. 142-145, 1972.
[13] Razi I and Havivi. Ifluence of chronic diabetes on tissue and blood cells status of zinc, copper, and chromium in the rats. Diabetes Research, vol. 7(1), pp. 19-23, 1988.

[14] Failla ML and Kiser RA. Hepatic and renal metabolism of copper and zinc in the diabetic rats. American Journal of Physiology, vol. 244(2), pp. E115-21, 1983.

[15] Akhuemokhan KI, Eregie A and Fasanmade OA. Trace mineral status and gly caemic control in Nigerians with type 2 diabetes. African Journal of Diabetes Medicine pp. 20-22, July 2010 .

[16] Kazi TG, Afridi HI, Kazi N, Jamali MK, Arain MB, Jalbani N et al. Copper, chromium, manganese, iron, nickel, and zinc levels in biological samples of diabetes mellitus patients. Biological Trace Element Research, vol. 122, pp. 1-18, 2008.

[17] Sasmita Tripathy, Sumathi S and Bhupal Raj G. Minerals Nutritional Status of Type 2 Diabetic Subjects. International. Journal of Diabetes in Developing Countries, vol.24, pp. 27-28, 2004.

[18] Nsonwu AC, Usoro CAO, Etukudo $\mathrm{MH}$ and Usoro IN. Glycaemic control and serum and urine levels of zinc and magnesium in diabetics in Calabar, Nigeria. Pakistan Journal of Nutrition, vol. 5(1), pp. 75-78, 2006

[19] Chausmer AB. Zinc, Insulin and diabetes, Journal of American College of Nutrition, vol. 17, pp.109-114, 1998.

[20] Garland HO. Magnesium deficiency in diabetes. Magnesium Research, vol. 5, pp. 193-202, 1992.

[21] Paolisso G. Magnesium. Diabetologia 1998; 31: 910-915

[22] Swain, R. and M.B. Kaplan, 1999. Magnesium for the next millennium, Syndrome. Scandinavian Journal of Gastroenterology, vol. 216(Suppl.), pp. 122-31, 1999.

[23] Arul Senghor, Bharathya N, Kumar JS, Ebenezer William, Balasubramaniam. Serum Ferritin, Iron, TIBC, $\mathrm{Hb}$ in male patients with dy sglycemia. International Journal of Biological and Medical Research, vol. 3(2), pp. 1609-1611, 2012.

[24] Duntas LH: Selenium and inflammation: underlying anti-inflammatory mechanisms. Hormone and Metabolic Research, vol. 41, pp. 443-447, 2009.

[25] Wiernsperger $\mathrm{N}$ and Rapin JR. Trace elements in glucometabolic disorders:an update. Diabetology \& Metabolic Syndrome, vol. 7, pp. 70, 2010.

[26] Ilouz R, Kaidanovich O, Gurwitz D, Eldar-Finkelman H: Inhibition of gly cogen synthase kinase-3beta by bivalent zinc ions: insight into the insulin-mimetic action of zinc. Biochemical and Biophysical Research Communication, vol. 295, pp. 102-106, 2002.

[27] Can B, Ulusu NN, Kilinc K, Ley la Acan N, Saran Y, Turan B: Selenium treatment protects diabetes-induced biochemical and ultrastructuralalterations in liver tissue. Biology of Trace Element Research, vol. 105, pp. 135-150, 2005.

[28] Prasad AS: Clinical, immunological, anti-inflammatory and antioxidant roles of zinc. Experimental Gerontology, vol43, pp. 370-377, 2008. 